\title{
A Study of Cultural Adaptation Process in Indonesia by PERSIB Football Club Foreign Players
}

\author{
$1^{\text {st* }}$ Reyna Arta Novia \\ Faculty of Communication Sciences \\ Universitas Pancasila \\ Jakarta, Indonesia \\ reynaarta@univpancasila.ac.id
}

\author{
$2^{\text {nd }}$ Faridhian Anshari \\ Faculty of Communication Sciences \\ Universitas Pancasila \\ Jakarta, Indonesia \\ faridhian@univpancasila.ac.id
}

\begin{abstract}
Basically, the adaptation that every individual goes through is not easy. The same is the case with foreign football players who play football far from their country who need adjustment in their new environment. This case is related to the three Persib Bandung foreign players namely Fabiano Beltrame from Brazil, Esteban Vizcarra from Argentina and Omid Nazari from the Philippines who play football in Indonesia. This study intends to find out the cultural adaptation process of foreign football players in Indonesia. The purpose of this research is to find out the process to adapt the culture of foreign football players in Indonesia and the process Indonesia in adopting the planning, honeymoon, frustration, readjustment and resolution phases. The foreign football players in Persib FC become these research instruments. The concepts used in this study are intercultural communication, culture shock, and cultural adaptation. However, this study uses a qualitative descriptive approach and depth interviews as the data collection techniques through with three informants namely Fabiano Beltrame, Esteban Vizcarra, and Omid Nazari as the foreign football players. Persib FC has the most foreign players' as many as six people than other clubs, so this research choose three players as the sources. The results of this research is there some process from the adaptations that have been carried out by the three informants in adopting the five phases, resulting in process made by the informants, including: learn the Indonesian language, studying Indonesian culture, interact with Indonesian people, try to marrying Indonesian, and last but not least is propose yourself as an Indonesian citizen.
\end{abstract}

Keywords - Cultural adaptation, foreign football players, Indonesia, and Persib FC

\section{INTRODUCTION}

Adaptation is a process of adjusting individuals or groups to norms, so that they can be adapted to the conditions that exist in their environment [1]. The adaptation usually takes place within the immigrant environment of students and workers because students and workers themselves are a very common profession [2]. Adaptation is a process after the individual goes through a cultural shock phase because that's when the process is passed by an individual who has just come into his new environment. Need special abilities to overcome cultural differences in new environments. The process of adaptation requires quite a long time, some processes can run smoothly and also otherwise [3]. In the process of adaptation, every individual must have many obstacles during the process so that the individual can feel comfortable with the conditions of his new environment [4].
It can be seen that the work of foreign athletes in Indonesia also requires adaptation, which is an adaptation in their work and environment. Adaptation in his work is an adjustment that can be described during training with his teammates or playing on the field against other teams [5]. Whereas in their environment is an adjustment in their daily lives when interacting with their surroundings outside their work to become an athlete. Athletes have challenges and obstacles when undergoing their profession, one of which must maintain their body condition and have a healthy lifestyle, although many athletes face a variety of demands, risks, and obstacles they face, it does not make them retreat to become an athlete, they persist and always try to overcome the existing obstacles, and consider a consequence they must face [6].

Athletes are jobs that are synonymous with sports, sports in Indonesia have many types including football, badminton, volleyball, tennis, and basketball. of the several branches of the sport, many achievements have been made and have been the name of Indonesia. One sport that is often popular nowadays in Indonesia is football, many Indonesians choose the profession as a football athlete because at this time football has become a work and business industry that can guarantee the survival of life. Thus, many football athletes are called footballers. Football in Indonesia is not just a popular sport, the results of a survey in 2017 reported that $77 \%$ of developing country people have an interest in football [7].

In Indonesia football league 2019, foreign football players are allowed with some rules. PT Liga Indonesia Baru (LIB) as an operator of the league still uses $3+1$ rules regarding foreign players. It means, each club in Indonesia may only use four foreign players with details, three coming from continental Europe, America, Africa, and the remaining one must have one Asian-Australian player. Restrictions on the use of foreign players need to be done, because this rule also supports the use of local players and young players in a 2019 League 1 club. Foreign players play in Indonesia on average for five to ten seasons in a row, they can start to feel happy and feel comfortable living in Indonesia. Foreign players who have lived in Indonesia have felt to learning the cultures, adapting to the surrounding environment. In the end, they decided to become Indonesian citizens and marry Indonesian people.

In 2010, there was a trend that foreign players decided to become Indonesian citizens such as Esteban Vizcarra, a 33year-old Argentine football player, completing the naturalization process and officially becoming an official Indonesian citizen in 2018. Since he first joined, he asked the club management to help him renounce Argentinian 
citizenship and become a naturalized player, this was supported by his marriage to a woman from Indonesia who strengthened his desire to change citizenship status. It is not easy to carry out the naturalization process for Esteban, because there are several things that he has to take care of so that he finally becomes an Indonesian citizen. Besides, Fabiano Beltrame, a Brazilian player who is a foreign defender at Persib Bandung, finally completed the naturalization process in the end of November 2019. Fabiano Beltrame had to go a long way to become an Indonesian citizen.

It can be seen that of the many clubs in Indonesia that have foreign players, Persib Bandung club has the most foreign players, there are six people. Divided to two persons who already become a citizen of Indonesia, and three persons from Europe and one person from southeast Asia.

The adaptation of foreign football players also connected with the euphoria from supporters and fans. Supporter is one of the driving elements of the football industry in Indonesia. Supporters are also described as a community, which always has the desire to find out all information about the club's pride [8]. Like the supporters of Persib, which called as Bobotoh, any movement of the players will be criticized including foreign football players. They will praise and criticize the players on the media or in the stadium of foreign players. Not all foreign footballers who play in the Indonesian league have a beautiful experience but they also have some complaints when playing in the Indonesian league, especially the complain about the supporter behaviors.

Based on the background explanation of the problem above, the problem formulation from this study is: How is the process of cultural adaptation by foreign players of Persib Football Club in Indonesia? After finding the results of the research questions, this study will provide some benefits like input for foreign nationals working in Indonesia with different cultural backgrounds, especially athletes or foreign football players who want a career in Indonesia.

\section{THEORETICAL REVIEW}

\section{A. Intercultural Communication}

Some research [9] says that intercultural communication occurs when members of one culture give a message to members of another culture. More precisely, intercultural communication involves interactions between people whose cultural perceptions and symbol systems are quite different in communication. So, from some of the above understanding, it can be concluded that communication between cultures is an interaction between one individual with another individual who has a different culture.

\section{B. Culture shock}

Culture shock is a feeling of anxiety and shock when an individual enters a new culture that is different from the culture that is inherent in him. The culture that is inherent when entering a new culture will not be effective because each culture has its way. Usually, people pass through four levels of culture shock that can be described in four ways. The first is the optimistic phase of the joy of entering a new culture. Second, the phase of cultural problems was the new environment begin to develop. Third, the healing phase where the individual begins to understand the new culture. Fourth, the adjustment phase where the individual has understood the key to new culture [10].

\section{Cultural Adaptation}

Some researchers also describe and describe the steps in the process of adopting a culture. In general, there are five phases, including [11]:

\section{1) Planning Phase}

The phase in which a person is still in his original state and prepares everything from physical endurance to mental, including the communication skills he has to prepare, which will be used in his new life.

\section{2) The Honeymoon Phase}

The phase where a person experiences excitement as the initial reaction of admiration, full of enthusiasm for new things, enthusiastic, friendly, and has a good relationship with the surrounding population. Someone has been in a new environment, adjusting to a new culture and environment.

\section{3) Frustration Phase}

The phase in which the attraction for new things from someone slowly begins to turn into frustration, where the sense of enthusiasm and curiosity turns into frustration, annoyance and not being able to do anything because the actual reality does not match the expectations at the beginning of the stage.

\section{4) Readjustment Phase}

The phase in which a person begins to resolve the crisis experienced in the frustrating phase. This stage is also a stage of readjustment, where someone will start to develop various ways to be able to adapt to the existing conditions. Someone begins to resolve the crisis experienced in the frustrating phase. This settlement is marked by the process of readjustment of someone to find ways, such as learning the language and local culture.

\section{5) Phase Resolution}

The final phase of the process of cultural adaptation is the last resort a person takes as a way out of the discomfort he feels. In this phase several things can be selected, namely Flight when someone cannot stand the environment and feel unable to make an effort to adapt more than what he has done and decided to leave the environment, a Fight is a person who enters the environment and culture new and he felt uncomfortable, but he tried to stay afloat and tried to deal with things that made him feel uncomfortable.

Accommodation is where a person tries to enjoy what is in his new environment, initially the person may feel uncomfortable [12], but they realizes that entering a new culture will indeed cause a little tension, so they also tries to compromise with the situation, both external and internal, and the full participation condition is when someone has begun to feel comfortable with their new environment and culture. Another research also said that these conditions contain the feeling of no more worry, anxiety, discomfort, and can overcome the frustration that was experienced in the past [13].

\section{RESEARCH METHOD}

The research approach used in this study is a qualitative approach with the type of descriptive research because it will explain in detail about the phenomena underlying this research 
[14]. By using this approach, researchers want to explain the culture adaptation process of foreign football players who play in the Indonesian league. Data collection techniques through interviews, where researchers conducted interviews with three Persib Bandung players namely Fabiano Beltrame, Esteban Vizcarra, and Omid Nazari. The reason of chossing Fabiano because he had a career in Indonesia for 14 years, has joined six clubs including Persela, Persemin, Persija, Arema FC, and Persib. Fabiano also officially became an Indonesian citizen in November 2019. The second informant was Esteban Vizcarra, and the reason why he is fit for this research because he had lived in Indonesia for 10 years, had joined five clubs including Pelita Jaya, Semen Padang FC, Arema FC, Sriwijaya FC, and Persib. Like Fabiano, Esteban officially became an Indonesian citizen in March 2018 and married an Indonesian citizen. The last informant was Omid Nazari, and the reason choosing him because Omid was a newcomer foreign football player who was undergoing an adaptation process.

\section{RESULT AND DISCUSSION}

For the analysis, researchers try to conclude it on a graphic.

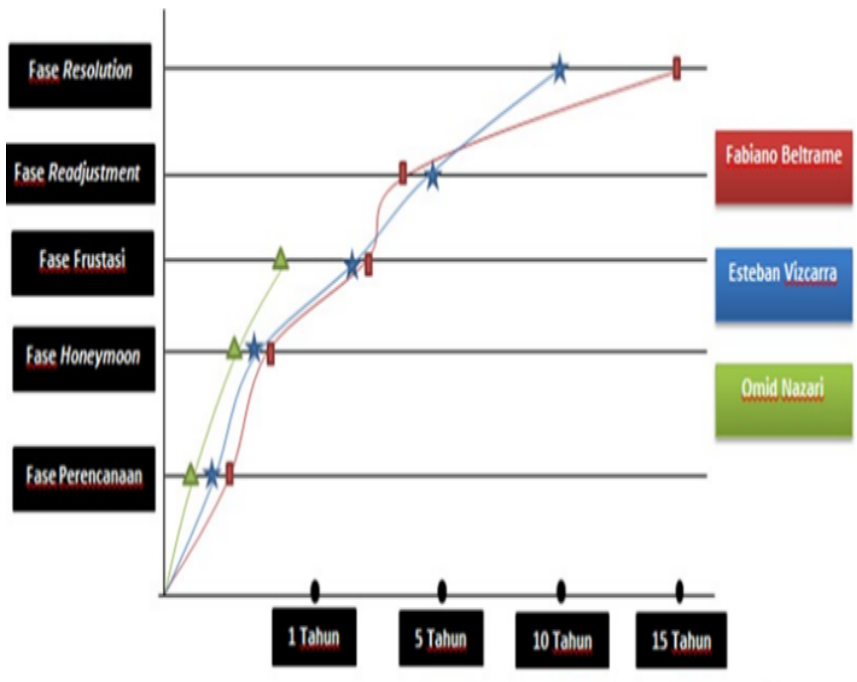

Fig. 1. The process of culture adaptation from the foreign football players

Based on the graph, it can be seen that in the planning phase experienced by Fabiano for less than a year. Likewise, it is the same with Esteban and Omid who experienced this phase for less than one year. In the honeymoon phase, Fabiano experienced that phase for less than one year, namely during the fifth month of his life while in the city of Lamongan, Esteban experienced the honeymoon phase in the third month when he lived in the city of Jakarta. However, Omid experienced that phase in the second month when he lived in the city of Bandung. The third phase is frustration, Fabiano's experiences that phase in the second year while living in Tomohon, similar to Esteban who experienced a frustrating phase in the second year when he lived in Padang, while Omid experienced a frustrating phase in less than one year, in the fifth month while he lives in Bandung.

The phase experienced by Omid only reached the frustration phase because the adaptation period experienced by the Filipino player was still relatively short. The fourth phase is the readjustment phase wherein this phase the informant experiences a readjustment from the frustration phase that has been experienced previously by the informant. Fabiano experienced a readjustment phase in the fourth year when he returned to play at the Persela club. While Esteban experienced a readjustment phase in the fifth year when he married a woman from Indonesia.

In the last phase of the resolution phase, Fabiano experienced that phase in the fifteen year when he lived in the country of Indonesia; he was officially an Indonesian citizen, while Esteban underwent a resolution phase in the 10th year which was marked by officially becoming Indonesian citizens in 2018. The results of research conducted by researchers show that the two foreign players namely Fabiano and Esteban have gone through five phases of cultural adaptation. While Omid only reached the frustration phase, Omid had not yet experienced the next phase because the adaptation period of the Filipino player was still relatively short.

In connection with the concept and describing the steps in the process of adopting a culture. In general, there are five phases, including: the planning phase is where a person is still in his original condition and preparing everything from physical endurance to mental, including the communication skills he has to prepare, which will be used in his new life. In the planning phase experienced by the three informants from Brazil, Argentina, and the Philippines who came to Indonesia only to play football, from observations made by researchers it appears that the three informants did not know much about the country of Indonesia, did not find out first how the situation in Indonesia or learn Indonesian first. Fabiano came to Indonesia to play football at first because his friend recommended the name Fabiano to the Persela Lamongan club, as he said in the interview:

"There used to be a friend from the same team in Brazil, he moved to Indonesia, Persela again looking for a defender, he gave my name, then I came here." (Interview with Fabiano Beltrame, 14 December 2019).

No special preparations were made, Fabiano only prepared equipment for playing football and important documents needed. Esteban Vizcarra who came to Indonesia through the help of agents. An agent from Indonesia recommended Esteban to play at the Jakarta Pelita Jaya club. At that time Esteban did not have a football club in Argentina and without thinking to much, he immediately took the opportunity to play football in Indonesia. Before coming to Indonesia to play football, he had a chance to look at a map to check the location of Indonesia that he could guess the existence of Indonesia with Argentina.

In terms of football, Argentina has made football as a promising business industry, so many people are competing to be a football player. The reason of Esteban chooses Indonesia as the country he wanted to play, because he believes that in Indonesia the life of football players was more promising compared to their home country, which had so many rivals to become football players. While the other foreign football player, Omid Nazari who came from Philippine, came to Indonesia through an agent that been contacted with the club. Omid only prepares his physique so that during the selection process at his new club, so he can provide maximum results. As he said in the interview as follows: 
"I just prepare for football and playing good in here". (Interview with Omid Nazari, 15 December 2019).

So, it can be seen that all informants when the first time they planned to play football in Indonesia are not associated with any club in their country. All informants experienced this phase less than one year.

In the honeymoon phase is a phase where individuals feel the joy, hope, and euphoria as an anticipation of the individual when dealing with a new culture. From observations made by researchers look happy feeling when explaining first came to his new environment. In the adaptation process in the honeymoon phase, Fabiano was happy when he arrived in Indonesia and lived in the city of Lamongan as the first city to be inhabited when he arrived in Indonesia. Fabiano was well received by his environment at that time so he began to feel comfortable with the hospitality of Indonesian people who he thought was very helpful when Fabiano arrived for the first time in Indonesia, especially when Fabiano was communicating with them. Esteban also felt the same thing, he was happy at the beginning of his arrival in Jakarta because he was excited to join and play football at his new club, Pelita Jaya Jakarta. Esteban considers that the club to be defended is good because it is located in the capital city of Indonesia.

Another player, Omid felt happy at the beginning of his arrival in Bandung because according to him, Bandung had a calm and cold atmosphere. Another informant, Esteban also said that he likes to communicate with Indonesians even though he uses English, but the Argentine player also wants to learn Indonesian so he can communicate smoothly with local players. Omid also has the same statement as Esteban that likes to communicate with Indonesians but is only hampered by language. In the third honeymoon phase, informants began to like Indonesian food. They like food that comes from Indonesia so it's not too difficult to accept it. In the honeymoon phase, Esteban also knew and had a relationship before he married his wife. In this phase, Fabiano experienced less than one year, namely during the fifth month when he lived in the city of Lamongan, Esteban informants experienced a honeymoon phase in the third month when he lived in the city of Jakarta. While Omid's informant experienced that phase in the second month when he lived in Bandung.

In the frustration phase where the attractiveness of new things from the individual slowly begins to turn into frustration. The sense of enthusiasm and curiosity experienced by the individual turns into frustration, so they are unable to do anything because the real reality is not following the expectations at the beginning of the stage. Cultural differences become an obstacle for the three foreign players in running a new life. This is a new task for the three foreign football players to understand cultural differences that are very far from their original culture. So that felt by the Brazilian informant experienced frustration while living in the city of Tomohon in 2007, Fabiano found it difficult to find the ingredients needed for food. Meanwhile, an Argentine informant, Esteban, felt frustrated while living in the city of Padang because he felt an earthquake that Esteban had never felt in his home country and was not used to listening to "Adzan" as the way muslim call people to pray. The three foreign football players from Brazil, Argentina, and the
Philippines also experienced homesickness because they missed their families. As Omid said:

"..because I'm lonely here so of course, I miss my friends, my family. Mostly just call, facetime on the phone" (Interview with Omid Nazari, 15 December 2019).

In the frustration phase, Fabiano is experienced that phase in the second year while living in Tomohon, similar to Esteban informants who experienced a frustrating phase in the second year when he lived in the city of Padang, while the Omid informant experienced a frustrating phase in less than one year that is, in the fifth month he lives in the city of Bandung. The phase experienced by Omid only reached the frustration phase because the adaptation period experienced was still going.

In the readjustment phase, where someone will start to develop various ways to be able to adapt to existing conditions. Foreign football players have also accepted Indonesian culture such as Esteban who have accepted that "Adzan" is part of the culture in Indonesia to remind time for worship. Because of mutual respect from cultural differences that make foreign football players begin at the stage of understanding the surrounding environment and understanding of the existing culture. Informants from Brazil and Argentina also learned Indonesian language to help facilitate communication with each other to produce the same understanding.

Studying Indonesian culture such as learning Sundanese language, respecting parents by kissing hands and learning to learn Indonesian habits by eating with hands is what Esteban did during the adaptation process. This was said by Esteban in the interview:

"Learning Indonesian, learning culture, people's habits here. Every day learning because living in the mess with local players every day learning. Learn to eat with your hands too" (Interview with Esteban Vizcarra, 18 December 2019).

Fabiano stated that one of the Indonesian cultures that would be applied in his life was about respect for parents because according to him politeness towards parents was very important to be applied in daily life which was supplemented by the following interview:

"When it comes to culture, the respect of children to parents I like, in Brazil is different, here from childhood they have always respected the older people" (Interview with Fabiano Beltrame, 14 December 2019).

In the readjustment phase, Fabiano experienced it in the fourth year when he returned to play at the Persela Lamongan club. While Esteban experienced in the fifth year when he married a woman from Indonesia. In the last phase of the resolution phase, people feel comfortable in a new culture and can work well. Not only feel comfortable with the environment, but also feel comfortable with the food and the people's habits.

In this phase, Fabiano and Esteban decided to become a lawful citizen by the state of Indonesia. The main reason for Esteban was the family factor, besides that in Argentina, the status of the other citizenship was not that much of a concern because regulations in Argentina said that it could have more than one citizen. By changing citizenship to Indonesian citizens, in the scope of work as a football player, his career 
can be guaranteed to be longer because he can play in league two. With the expression that states:

"In 2015 there were plans, but they were hampered by documents and other things. The reason is that I have been here for a long time and like Indonesia, have been adapted, have a wife and children, so they are used to it all" (Interview with Esteban Vizcarra, 18 December 2019).

The reason for Fabiano to transfer citizenship from Brazil to Indonesia is that he could pursue a longer career in Indonesia, and he said that if he became a citizen, he would continue to pay for a residence permit. As for the economic factors that caused the two informants to decide to change citizenship and decide to settle in Indonesia. According to Esteban, in Argentina, the cost of living was higher than Indonesia. In contrast to Fabiano's informant who stated that the cost of living in Brazil was the same as Indonesia. In the resolution phase, Fabiano experienced that phase in his fifteenth year when he lived in the country of Indonesia. In that year, he was officially an Indonesian citizen, while Esteban underwent a resolution phase in his tenth year which was marked by officially becoming an Indonesian citizen in 2018 .

In this phase, several things can be made choices when they have successfully passed the adaptation process, in this phase informants Fabiano and Esteban have the results of full participation, which is when someone has begun to feel comfortable with their new environment and culture. No more worries, anxieties, discomforts, and can overcome the frustrations that were experienced in the past so that both informants were received in their new environment because they succeeded through the adaptations they made in their new environment. The influence of the environment left behind is very supportive to go through the process of adaptation of the foreign players so that the two foreign players can go through the process of adaptation with happy feelings without coercion.

\section{CONCLUSION}

From the adaptations that have been carried out by the three informants in adopting the five phases, resulting in process made by the informants, including: learn the Indonesian language, studying Indonesian culture, interact with Indonesian people, try to marrying Indonesian, and last but not least is propose yourself as an Indonesian citizen.

Based on research on adaptation process undertaken by foreign football players in Indonesia, it can be concluded that the adaptation process must be experienced by anyone when they leave their original place and move to their new place. The process of adaptation is very necessary to live life in a new environment because there are so many dynamics that occur so that the culture shock is often encountered by every human being. By learning the facts about the new environment, a person will begin to choose what is good and what is bad for him, which is right and which is wrong. Then finally how much someone's desire to be able to unite their views or even differentiate themselves depends on the motivation they have to be able to survive in the new environment.

Based on the results, the researchers will give some suggestions to foreign football players who wants to quickly adapt. In the planning phase, it is better before coming to a new environment, foreign football players find out in advance the state of the country they want to visit and learn the language even if only a little. Second, in the honeymoon phase, it is best for every individual who moves from their home country to be prepared for the process of adaptation. Foreign football players must be aware of the process of coping a culture adaptation because this is a fundamental problem that experienced by every individual when they come to new place with different cultural background.

The third phase is the frustration phase, informants should understand and respect differences when living in different environments so that avoid conflict to create a feeling of comfort in the new environment and also, they need to be open to the new culture so that it can overcome the problem when adapting. In the readjustment phase, they should learn to adapt without judging if your ethnicity or region or culture is the best compared to other regions in Indonesia so that the adaptation will run smoothly when interacting with people who indeed have different tribes and also different customs.

Finally, in the resolution phase, which is learning to understand other people's cultures, is the key to achieve effective communication. It is better to be more active in finding out the culture and values adopted by the people in the new environment to minimize the culture shock that occurs so that they can quickly adapt to the process.

\section{REFERENCES}

[1] Tangkudung, Josep. P. M. "Proses Adaptasi Menurut Jenis Kelamin Dalam Menunjang Studi Mahasiswa Fisip Universitas Sam Ratulangi”. Journal “Acta Diurna”, Vol. 3. No.4, pp 320-332. Juni 2014.

[2] Shi, Ling and Wang, Lei. "The Culture Shock and Cross-Cultural Adaptation of Chinese Expatriates in International Business Contexts". Journal of, International Business Research. Vol. 7, No. 1, pp 55-56. June 2013.

[3] Ridwan, Aang. Komunikasi Antarbudaya. Bandung: CV Pustaka Setia, 2016.

[4] Beaven, Ana M. and Oatey, Helen. S. "Cultural adaptation in different facets of life and the impact of language". JoLanguage and Intercultural Communication. Vol 16 no 3 pp. 349-367. June, 2016.

[5] Muttaqin, Anandya. I and Supraptiningsih, Endang. "Character Strength Pada Atlet Penyandang Tuna Daksa Di Npci Kota Bandung." Journal of Psychological Research. Vol. 3, No.1, pp 58-68, Mei 2017.

[6] Boyle, Raymond. and Haynes, Richard. Power, Play, Sport, the Media, and Popular Culture. Second Edition: Edinburgh University Press Ltd. UK, 2009.

[7] Fauzi, Rochmat and Anshari, Faridhian. "Analisis Experiental Marketing dalam Stasiun Radio Berformat Olahraga; Studi Pada Program Off Air Nonton Bareng Radio 96.4 Bobotoh FM Bandung”. Jurnal Komunikasi dan Media (Commed); Universitas Putera Batam. Vol 1, No 2, pp 66 - 75, Febuari 2017. ISSN: 2527-8673.

[8] Anshari, Faridhian. Fauzia, Silva. and Fungky, Yuliana. "Tren Supporter Bersuara Melalui Media. Meraba Strategi Eksistensi Media Kreasi Bobotoh Persib Bandung". Prossiding The Power of Communication; Komunikasi, Media, dan Dinamika Sosial. Asosiasi Pendidikan Tinggi Ilmu Komunikas. Vol 1 pp 311-319, Sept 2016.

[9] Samovar, Larry. Porter, Richard and McDaniel, Edwin. Komunikasi Lintas Budaya Edisi 7. Jakarta: Salemba Humanika, 2017.

[10] Maulidia, Indah. "Culture Shock Dalam Interaksi Komunikasi Antarbudaya Pada Mahasiswa Asal Papua Di USU”. Jurnal Universitas Sumatera Utara. Vol. 3, No. 1, pp 92 - 104 Juni 2016.

[11] Ruben, Brent. D, and Stewart, Lea P. Komunikasi dan Perilaku Manusia (Edisi kelima). Jakarta: Rajawali Pers, 2013.

[12] Mulyana, Deddy. Komunikasi Antarbudaya Panduan Berkomunikasi Dengan Orang-Orang Berbeda Budaya. Bandung: Remaja Rosdakarya, 2000 .

[13] Utami, Lusia. S. "Teori-Teori Adaptasi Antar Budaya”. Jurnal Komunikasi. Vol. 7, No. 2, pp 18. Desember 2015.

[14] Creswell, John. W. Research Design Pendekatan Kualitatif, Kuantitatif, dan Mixed. Yogyakarta: Pustaka Pelajar, 2016. 